\title{
PROFESIONALITAS GURU PAI DI SMAN 2 SEMARANG
}

\author{
Lina Agustina, M.Pd.I \\ STAI Attanwir Bojonegoro \\ linaagustina890@gmail.com
}

\begin{abstract}
In this study, the problem that arises is how the Islamic Education Teacher Professionalism associated with the 4 competencies of teachers and Teacher Academic Qualification as listed in the laws. How can a teacher be able to develop the four competencies required of qualified academic and inline with the subjects of teaching. The extent to which a teacher was able to carry out the responsibilities and duties - duties properly. Not only the responsibility for learning in the classroom but how learners are able to actualize in daily life - today.

The informants of this study was teacher of Islamic education at the Senior High School 2 Semarang and learners in the school environment. Research on the professionalism of teachers of Islamic education in the National High School 2 Semarang, using the technique of collecting data through interviews, observation and documentation. The analysis model used in this study is komponensial domain analysis.

The results obtained show that, as a professional educator should not only academically, but personality and way of socializing with the environment is also become very important. Moreover, a teacher with a good personality and social will be a lot of good influence to the learners. Because teachers with personal and social wellcapable of being role models for their students.
\end{abstract}

Keywords : professionality, Islamic Education Teachers

Abstrak

Permasalahan yang muncul dalam penelitian ini adalah bagaimana Profesionalitas Guru PAI terkait dengan 4 kompetensi guru dan Kualifikasi Akademik Guru seperti yang tercantum dalam undang - undang. Bagaimana seorang guru mampu mengembangkan keempat kompetensi yang harus dimiliki serta mempunyai kualifikasi akademik yang sejalur dengan mata pelajaran yang diampu. Sejauh mana seorang guru itu mampu melaksanakan tanggung jawab serta tugas - tugasnya dengan baik dan benar. Bukan hanya tanggung jawab dalam pembelajaran di kelas tetapi bagaimana peserta didik mampu mengaktualisasikannya dalam kehidupan sehari - hari.

Adapun informan dari penelitian ini adalah guru PAI di SMAN 2 Semarang dan peserta didik yang ada di lingkungan sekolah. Penelitian tentang profesionalitas guru PAI di SMAN 2 Semarang, menggunakan teknik pengumpulan data melalui wawancara, observasi dan dokumentasi. Model analisis yang digunakan dalam penelitian ini adalah analisis domain komponensial.

Hasil penelitian yang diperoleh menunjukkan bahwa, sebagai seorang pendidik tidak harus profesional secara akademik saja, akan tetapi kepribadian dan cara bersosialisasi dengan lingkunagan juga menjadi sangat penting. Terlebih seorang guru dengan kepribadian dan sosial yang baik akan banyak memberikan pengaruh yang baik terhadap peserta didiknya. Karena guru dengan pribadi dan sosial yang baik mampu menjadi teladan bagi peserta didiknya.

Kata kunci: profesionalitas, Guru PAI. 


\section{A. PENDAHULUAN}

Dalam dunia pendidikan komponen terpenting adalah guru atau pendidik. Guru merupakan pembimbing dan pendidik yang akan mengantarkan peserta didik mencapai tujuan pendidikan nasional sebagai mana yang tercantum dalam pasal 3 Undang - Undang Republik Indonesia No. 20 Tahun 2003 tentang Sistem Pendidikan Nasional, yang berbunyi: "Pendidikan nasional bertujuan untuk berkembangnya potensi peserta didik agar menjadi manusia yang beriman dan bertakwa kepada Tuhan Yang Maha Esa, berakhlak mulia, sehat, berilmu, cakap, kreatif, mandiri, dan menjadi warga negara yang demokratis serta bertanggung jawab."

Guru dituntut memiliki kualifikasi akademik dan kompetensi sebagai pendidik dan pembimbing, yang sehat secara jasmani maupun rohani serta memiliki kemampuan untuk mewujudkan tujuan pendidikan nasional. Seorang guru tidak hanya seorang yang mampu mengajarkan segala sesuatu kepada peserta didik, akan tetapi demi mewujudkan tujuan pendidikan seorang guru harus mempunyai standar kualifikasi akademik.

Untuk menjadi seorang guru profesional yang bertanggung jawab penuh terhadap tugas - tugasnya, seorang guru harus mempunyai standar kompetensi. Standar kompetensi guru ditujukan untuk mendapatkan acuan baku dalam pengukuran kinerja guru sebagai jaminan kualitas guru dalam upaya peningkatan kualitas proses pembelajaran (Madjid, 20I I).

Guru dianggap sebagai seorang yang sudah berpengalaman dan sepantasnya mengajarkan hal - hal yang dapat dipertanggung jawabkan kebenarannya serta memberikan manfaat. Jika yang diberikan tidak memiliki dasar kebenaran keilmuan yang kukuh serta tidak ada manfaatnya untuk perkembangan anak didik, maka mengajar akan kehilangan relevansinya bagi guru. Tidak semua orang mampu menjadi guru, hanya mereka yang mempunyai kemampuan untuk menanamkan nilai - nilai kebenaran serta memberikan pengetahuan yang benar - benar dapat diambil manfaatnya.

Dalam peranannya yang sangat penting tersebut, tidak semua orang mampu menjadi sebagai guru yang benar - benar melaksanakan tugasnya dengan baik. Oleh karena itu seorang guru dituntut untuk memiliki kompentensi serta kualifikasi pendidikan sesuai dengan jenjang pendidikan masing - masing. Kompetensi adalah seperangkat kemampuan yang harus dimiliki oleh seorang guru dalam melaksanakan tanggung jawabnya sebagai seorang guru.

Seperti yang tercantum dalam UU Sisdiknas bab VI pasal 28 ayat 3 tentang Standar Pendidik dan Tenaga Kependidikan yang berbunyi: "Kompetensi sebagai agen pembelajaran pada jenjang pendidikan dasar dan menengah serta pendidikan anak usia dini meliputi: (a). Kompetensi pedagogik. (b). Kompetensi kepribadian. (c). Kompetensi profesional dan, (d). Kompetensi sosial”.

Dengan memiliki keempat kompetensi tersebut, diharapkan guru - guru disekitar kita khususnya guru PAI mampu menjadi seorang pendidik yang profesional. Karena guru profesional mempunyai tanggung jawab sosial, intelektual, moral dan spiritual (Mudlofir: 20I2). Banyak guru disekitar kita yang belum sepenuhnya menyadari akan tugas - tugasnya serta profesinya sebagai seorang pendidik.

Guru beranggapan bahwa hanya dengan mengajar saja sudah cukup mewakili tugas - tugas mereka. Banyak lembaga - lembaga pendidikan yang tidak peduli terhadap kondisi para pendidiknya, mereka beranggapan guru itu hanya bertugas mengajar cukup dengan datang dan mengajar di kelas. Selain itu, banyak masyarakat yang beranggapan bahwa adanya guru guru yang tidak mempunyai standar kualifikasi dan kompetensi yang menyebabkan perilaku - perilaku yang tidak baik terhadap anak - anak mereka. Seperti halnya penelitian yang dilakukan oleh Darmansyah dalam tesis yang berjudul "Kontribusi Profesionalisme Guru dan Kepemimpinan Kepala Sekolah terhadap Kinerja Guru SMP Negeri di Kabupaten Brebes”. Dalam penelitian tersebut persentase profesionalisme guru sangat minim sekali yaitu $17,6 \%$, yang artinya masih perlu peningkatan kinerja guru.

Jika mengacu pada keempat kompetensi tersebut, guru yang profesional tidak hanya mampu mengajar peserta didiknya. Akan tetapi lebih dari itu, yaitu sebagai pelatih, pembimbing, pengevaluasi, penilai dan pengarah bagi peserta didiknya. Termasuk juga menanamkan nilai - nilai agama dan moral kepada peserta didiknya. 


\section{B. METODE PENELITIAN}

Jenis penelitian yang akan dipakai adalah field research (penelitian lapangan). Peneliti akan mengumpulkan data dari kenyataan yang terjadi di lapangan secara terus menerus (Moleong, 2012). Dalam penelitian kualitatif tidak menggunakan populasi karena berangkat dari kasus dan situasi sosial tertentu yang hasil penelitian tidak berlaku untuk populasi, melainkan ditransferkan ke situasi sosial yang memiliki kesamaan dengan permasalahan yang diteliti. Sampel dalam penelitian kualitatif disebut dengan nara sumber, informan, partisipan, teman dan guru dalam penelitian (Sugiyono, 2013).

Subjek penelitian adalah guru PAI di SMAN 2 Semarang. Penelitian ini dilakukan terhadap satu orang guru, menurut Lincoln dan Guba peneliti memilih orang tertentu yang diyakini mampu memberikan data dan informasi yang diperlukan. Inilah yang disebut sebagai "serial selection of sample units". Oleh karena itu, jika satu guru dianggap sudah memenuhi fokus penelitian. Maka, penelitian dilakukan terhadap satu guru PAI di SMAN 2 Semarang. Objek penelitian dalam penelitian kualitatif adalah situasi sosial. Pada situasi sosial peneliti dapat mengamati secara mendalam aktivitas orang orang yang berada di tempat tertentu (Sugiyono, 2013). Dalam penelitian ini yang menjadi objek penelitian adalah aktivitas guru PAI di SMAN 2 Semarang ditinjau dari segi profesionalitasnya.

Dalam penelitian ini akan digunakan beberapa teknik pengumpulan data yaitu: (a). Interview (wawancara) dimana teknik ini digunakan agar data yang diperoleh lebih akurat untuk mendapatkan informasi langsung dari guru PAI di SMAN 2 Semarang. Dalam penelitian ini akan digunakan wawancara tak terstruktur atau disebut dengan wawancara mendalam (wawancara kualitatif) (Mulyana, 20I0). Dengan wawancara ini akan didapatkan data yang lebih dalam karena pertanyaan yang diajukan akan berkembang sesuai dengan kebutuhan penelitian. Instrumen yang akan dipakai dalam teknik pengumpulan data melalui wawancara yaitu dengan menggunakan peneliti sebagai pewawancara yang akan mengajukan beberapa pertanyaan kepada guru PAI di SMAN 2 Semarang; (b). Observasi, dalam penelitian ini digunakan teknik observasi karena peneliti akan mengamati secara langsung aktivitas guru PAI di SMAN 2 Semarang. Observasi yang digunakan adalah observasi berperan serta, dengan teknik ini peneliti dapat berpartisipasi dalam rutinitas subjek penelitian baik mengamati apa yang mereka lakukan, mendengarkan apa yang mereka katakan bahkan menanyai orang orang di sekitar mereka dalam jangka waktu tertentu (Mulyana, 2010). Instrumen atau alat pengumpul data yang digunakan dalam teknik pengumpulan data melalui observasi yaitu dengan menggunakan check list (daftar cek). Daftar cek digunakan untuk mengamati aktivitas guru PAI di SMAN 2 Semarang; (c). Dokumentasi, teknik pengumpulan data yang ketiga adalah dokumentasi. Dokumentasi digunakan untuk melengkapi data dari hasil wawancara maupun observasi (Mulyana, 20I0). Dokumentasi dilakukan dengan mengumpulkan catatan yang sudah berlalu seperti bahan atau materi pembelajaran, silabus, rencana pelaksanaan pembelajaran dan data-data pribadi guru PAI maupun sekolah di SMAN 2 Semarang.

Keabsahan data dalam penelitian ini menggunakan 2 kriteria yaitu: (a). Perpanjangan Keikutsertaan; (b). Ketekunan / Keajegan pengamatan. Sedangkan analisis data yang digunakan adalah analisis data deskriptif kualitatif, dikatakan deskriptif karena data dalam penelitian ini akan digambarkan oleh peneliti dalam bentuk kata - kata dan gambar. Dikatakan kualitatif karena dalam penelitian ini, analisis data yang dilakukan tidak hanya setelah penelitian tetapi juga sebelum maupun ketika penelitian itu berlangsung (Kasiram: 20I0).

Dengan proses penelitian yang panjang maka data yang diperoleh akan semakin mendalam yaitu data tentang profesionalitas guru PAI di SMAN 2 Semarang. Dalam penelitian ini, peneliti diharuskan memiliki gambaran tentang profesionalitas guru PAI di SMAN 2 Semarang yang diperoleh melalui hasil pengumpulan data di lapangan dengan membuat sebuah catatan. Catatan tersebut yang kemudian disebut dengan catatan kualitatif (Putra, 20I2).

Sebelum analisis dilakukan ketika peneliti masuk ke lapangan, dilakukan terlebih dahulu analisis sebelum ke lapangan. Sebelum peneliti masuk ke lapangan, dalam penelitian kualitatif sudah dilakukan 
analisis data sebelum di lapangan. Analisis ini dilakukan untuk menentukan fokus yang masih bersifat sementara. Setelah penelitian dilakukan, fokus akan berubah sesuai kebutuhan penelitian.

Dalam analisis data di lapangan, peneliti menggunakan model analisis lapangan model spradley. Langkah pertama yang diambil oleh peneliti adalah melakukan analisis domain yang kemudian dilanjutkan dengan analisis taksonomi yang aktivitasnya adalah menjabarkan domain yang dipilih ke dalam bentuk yang lebih rinci. Kemudian analisis komponensial adalah mencari perbedaan yang spesifik dari rincian tersebut. Yang terakhir dilakukan adalah analisis tema budaya, yang berfungsi untuk mencari hubungan antara domain, serta bagaimana hubungannya dengan keseluruhan (Sugiyono, 2013).

\section{PEMBAHASAN}

\section{Kompetensi Guru PAI}

Dalam Undang - undang telah dijelaskan bahwa seorang guru harus mempunyai 4 kompetensi yaitu: kompetensi pedagogik, kompetensi kepribadian, kompetensi sosial dan kompetensi profesional. Masing - masing kompetensi mempunyai beberapa indikator. Dalam hasil penelitian yang diperoleh di SMAN akan dilakukan analisis sebagai berikut:

a.Kompetensi Kepribadian

Kompetensi kepribadian adalah kemampuan kepribadian yang mantap, stabil, dewasa, arif dan berwibawa, menjadi teladan bagi peserta didik dan berakhlak mulia. Berikut ini akan disajikan indikator - indikator kompetensi kepribadian berdasarkan Permendiknas Republik Indonesia No. I6 Tahun 2007 tentang Standar Kualifikasi Akademik dan Kompetensi Guru:

Tabe1 5.I Indikator - Indikator Kompetensi Kepribadian

\begin{tabular}{|l|l|c|}
\hline No & Kompetensi Inti Kompetensi & \multicolumn{1}{c|}{ Guru Mata Pelajaran } \\
\hline $\begin{array}{l}\text { Menguasai karakteristik } \\
\text { peserta didik dari aspek fisik, } \\
\text { moral, spiritual, sosial, kultural, } \\
\text { emosional, dan intelektual. }\end{array}$ & $\begin{array}{r}\text { I.I Memahami karakteristik peserta didik yang berkaitan dengan aspek fisik, } \\
\text { intelektual, sosial-emosional, moral, spiritual, dan latar belakang sosial- } \\
\text { budaya. } \\
\text { I.2 } \begin{array}{l}\text { Mengidentifikasi potensi peserta didik dalam mata pelajaran yang } \\
\text { diampu. } \\
\text { Mengidentifikasi bekal-ajar awal peserta didik dalam mata pelajaran } \\
\text { yang diampu. }\end{array}\end{array}$ \\
\hline
\end{tabular}




\begin{tabular}{|c|c|c|}
\hline & & $\begin{array}{l}\text { I.4 Mengidentifikasi kesulitan belajar peserta didik dalam mata pelajaran yang } \\
\text { diampu. }\end{array}$ \\
\hline 2 & $\begin{array}{l}\text { Menguasai teori belajar dan } \\
\text { prinsip-prinsip pembelajaran } \\
\text { yang mendidik }\end{array}$ & $\begin{array}{l}\text { 2.I Memahami berbagai teori belajar dan prinsip-prinsip pembelajaran yang mendidik } \\
\text { terkait dengan mata pelajaran yang diampu. } \\
\text { 2.2 Menerapkan berbagai pendekatan, strategi, metode, dan teknik pembelajaran yang } \\
\text { mendidik secara kreatif dalam mata pelajaran yang diampu. }\end{array}$ \\
\hline 3 & $\begin{array}{l}\text { Mengembangkan kurikulum } \\
\text { yang terkait dengan mata } \\
\text { pelajaran yang diampu. }\end{array}$ & $\begin{array}{l}\text { 3.I Memahami prinsip-prinsip pengembangan kurikulum. } \\
\text { 3.2 Menentukan tujuan pembelajaran yang diampu. } \\
\text { 3.3 Menentukan pengalaman belajar yang sesuai untuk mencapai tujuan pembelajaran } \\
\text { yang diampu. } \\
\text { 3.4 Memilih materi pembelajaran yang diampu yang terkait dengan pengalaman } \\
\text { belajar dan tujuan pembelajaran. } \\
\text { 3.5 Menata materi pembelajaran secara benar sesuai dengan pendekatan yang dipilih } \\
\text { dan karakteristik peserta didik. } \\
\text { 3.6 Mengembangkan indikator dan instrumen penilaian. }\end{array}$ \\
\hline 4 & $\begin{array}{l}\text { Me n y e le } \mathrm{ng} g \text { a rakan } \\
\text { pembelajaran yang mendidik. }\end{array}$ & $\begin{array}{l}\text { 4.I Memahami prinsip-prinsip perancangan pembelajaran yang mendidik. } \\
\text { 4.2 Mengembangkan komponen-komponen rancangan pembelajaran. } \\
\text { 4.3 Menyusun rancangan pembelajaran yang lengkap, baik untuk kegiatan di dalam } \\
\text { kelas, laboratorium, maupun lapangan. } \\
\text { 4.4 Melaksanakan pembelajaran yang mendidik di kelas, di laboratorium, dan di } \\
\text { lapangan dengan memperhatikan standar keamanan yang dipersyaratkan. } \\
\text { 4.5 Menggunakan media pembelajaran dan sumber belajar yang relevan dengan } \\
\text { karakteristik peserta didik dan mata pelajaran yang diampu untuk mencapai } \\
\text { tujuan pembelajaran secara utuh. } \\
\text { 4.6 Mengambil keputusan transaksional dalam pembelajaran yang diampu sesuai } \\
\text { dengan situasi yang berkembang. }\end{array}$ \\
\hline 5 & $\begin{array}{l}\text { Memanfaatkan teknologi } \\
\text { informasi dan komunikasi } \\
\text { untuk kepentingan } \\
\text { pembelajaran. }\end{array}$ & $\begin{array}{l}\text { 5.I Memanfaatkan teknologi informasi dan komunikasi dalam pembelajaran yang } \\
\text { diampu }\end{array}$ \\
\hline 6 & $\begin{array}{l}\text { Memfasilitasi pengembangan } \\
\text { potensi peserta didik untuk } \\
\text { mengaktualisasikan berbagai } \\
\text { potensi yang dimiliki. }\end{array}$ & $\begin{array}{l}\text { 6.I Menyediakan berbagai kegiatan pembelajaran untuk mendorong peserta didik } \\
\text { mencapai prestasi secara optimal. } \\
\text { 6.2 Menyediakan berbagai kegiatan pembelajaran untuk mengaktualisasikan potensi } \\
\text { peserta didik, termasuk kreativitasnya. }\end{array}$ \\
\hline 7 & $\begin{array}{l}\text { Berkomunikasi secara efektif, } \\
\text { empatik, dan santun dengan } \\
\text { peserta didik. }\end{array}$ & $\begin{array}{l}\text { 7.I Memahami berbagai strategi berkomunikasi yang efektif, empatik, dan santun, } \\
\text { secara lisan, tulisan, dan/atau bentuk lain. } \\
\text { 7.2 Berkomunikasi secara efektif, empatik, dan santun dengan peserta didik dengan } \\
\text { bahasa yang khas dalam interaksi kegiatan/permainan yang mendidik yang } \\
\text { terbangun secara siklikal dari (a) penyiapan kondisi psikologis peserta didik untuk } \\
\text { ambil bagian dalam permainan melalui bujukan dan contoh, (b) ajakan kepada } \\
\text { peserta didik untuk ambil bagian, (c) respons peserta didik terhadap ajakan guru, } \\
\text { dan (d) reaksi guru terhadap respons peserta didik, dan seterusnya }\end{array}$ \\
\hline & $\begin{array}{l}\text { Menyelenggarakan penilaian } \\
\text { dan evaluasi proses dan hasil } \\
\text { belajar. }\end{array}$ & $\begin{array}{l}\text { 8.I Memahami prinsip-prinsip penilaian dan evaluasi proses dan hasil belajar sesuai } \\
\text { dengan karakteristik mata pelajaran yang diampu. } \\
\text { 8.2 Menentukan aspek-aspek proses dan hasil belajar yang penting untuk dinilai dan } \\
\text { dievaluasi sesuai dengan karakteristik mata pelajaran yang diampu. } \\
\text { 8.3 Menentukan prosedur penilaian dan evaluasi proses dan hasil belajar. } \\
\text { 8.4 Mengembangkan instrumen penilaian dan evaluasi proses dan hasil belajar. } \\
\text { 8.5 Mengadministrasikan penilaian proses dan hasil belajar secara berkesinambungan } \\
\text { dengan mengunakan berbagai instrumen. }\end{array}$ \\
\hline
\end{tabular}




\begin{tabular}{|c|c|c|}
\hline & & $\begin{array}{l}\text { 8.6 Menganalisis hasil penilaian proses dan hasil belajar untuk berbagai tujuan. } \\
\text { 8.7 Melakukan evaluasi proses dan hasil belajar. }\end{array}$ \\
\hline 9 & $\begin{array}{l}\text { Memanfaatkan hasil } \\
\text { penilaian } \\
\text { dan evaluasi untuk } \\
\text { kepentingan pembelajaran. }\end{array}$ & $\begin{array}{l}\text { 9.I Menggunakan informasi hasil penilaian dan evaluasi untuk menentukan ketuntasan } \\
\text { belajar } \\
\text { 9.2 Menggunakan informasi hasil penilaian dan evaluasi untuk merancang program } \\
\text { remedial dan pengayaan. } \\
\text { 9.3 Mengkomunikasikan hasil penilaian dan evaluasi kepada pemangku kepentingan. } \\
\text { 9.4 Memanfaatkan informasi hasil penilaian dan evaluasi pembelajaran untuk } \\
\text { meningkatkan kualitas pembelajaran. }\end{array}$ \\
\hline & $\begin{array}{l}\text { Melakukan tindakan } \\
\text { reflektif untuk peningkatan } \\
\text { kualitas } \\
\text { pembelajaran. }\end{array}$ & $\begin{array}{l}\text { IO.I Melakukan refleksi terhadap pembelajaran yang telah dilaksanakan. } \\
\text { I0.2 Memanfaatkan hasil refleksi untuk perbaikan dan pengembangan pembelajaran } \\
\text { dalam mata pelajaran yang diampu. } \\
\text { I0.3 Melakukan penelitia tindakan kelas untuk meningkatkan kualitas pembelajaran } \\
\text { dalam mata pelajaran yang diampu. }\end{array}$ \\
\hline
\end{tabular}

Guru membuat beberapa perangkat pembelajaran, diantaranya yaitu silabus, program tahunan, analisis kompetensi dasar, dan rancangan pelaksanaan pembelajaran (RPP) setiap harinya. Guru juga menggunakan berbagai macam bahan ajar (buku ajar), karena menurut menurutnya buku ajar yang digunakan tidak sesuai dengan kurikulum. Terkadang materi yang tidak ada dalam buku ajar terdapat dalam buku yang lain. Dengan kata lain antara satu buku dengan yang lainsaling melengkapi. Guru juga menunjukkan buku - buku yang tidak lengkap (tidak sesuai). Dalam pemilihan metode, guru juga menyesuaikannya dengan materi pembelajaran, seperti yang dituturkan beliau dalam wawancara langsung materi tentang kajian terhadap ayat-ayat Al Qur'an menggunakan metode diskusi, materi yang berhubungan dengan perilaku menggunakan metode bermain peran.

Dalam sistem penilaian, guru menggunakan penilaian proses. Dengan kata lain siswa dengan akhlak yang baik akan mendapatkan nilai tambahan dalam pelajaran PAI.

c. Kompetensi Sosial

Kompetensi sosial adalah kemampuan pendidik sebagai bagian dari masyarakat untuk berkomunikasi dan bergaul secara efektif dengan peserta didik, sesama pendidik, tenaga kependidikan, orang tua / wali peserta didik dan masyarakat sekitar. Berikut akan disajikan beberapa indikator dari kompetensi sosial menurut Permendiknas Republik Indonesia No. I6 Tahun 2007 tentang Standar Kualifikasi Akademik dan Kompetensi Guru: 
Tabel 5.3 Indikator - Indikator Kompetensi Sosial

\begin{tabular}{|c|c|c|}
\hline No & Kompetensi Inti & Kompetensi Guru Mata Pelajaran \\
\hline I & 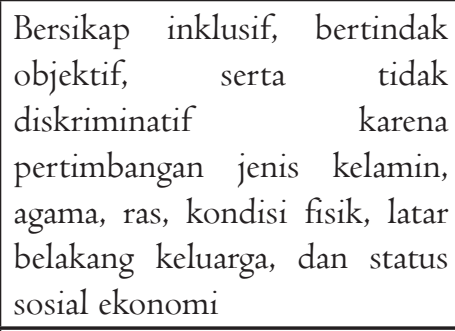 & $\begin{array}{l}\text { I.I Bersikap inklusif dan objektif terhadap peserta didik, teman sejawat dan } \\
\text { lingkungan sekitar dalam melaksanakan pembelajaran. } \\
\text { I.2 Tidak bersikap diskriminatif terhadap peserta didik, teman sejawat, orang } \\
\text { tua peserta didik dan lingkungan sekolah karena perbedaan agama, suku, jenis } \\
\text { kelamin, latar belakang keluarga, dan status sosial-ekonomi. }\end{array}$ \\
\hline 2 & $\begin{array}{l}\text { Berkomunikasi secara efektif, } \\
\text { empatik, dan santun dengan } \\
\text { sesama pendidik, tenaga } \\
\text { kependidikan, orang tua, dan } \\
\text { masyarakat. }\end{array}$ & $\begin{array}{l}\text { 2.I Berkomunikasi dengan teman sejawat dan komunitas ilmiah lainnya secara } \\
\text { santun, empatik dan efektif. } \\
\text { 2.2 Berkomunikasi dengan orang tua peserta didik dan masyarakat secara santun, } \\
\text { empatik, dan efektif tentang program pembelajaran dan kemajuan peserta } \\
\text { didik. } \\
\text { 2.3 Mengikutsertakan orang tua peserta didik dan masyarakat dalam program } \\
\text { pembelajaran dan dalam mengatasi kesulitan belajar peserta didik. }\end{array}$ \\
\hline 3 & $\begin{array}{l}\text { Beradaptasi di tempat bertugas } \\
\text { di seluruh wilayah Republik } \\
\text { Indonesia yang memiliki } \\
\text { keragaman sosial } \\
\text { budaya. }\end{array}$ & $\begin{array}{l}\text { 3.I Beradaptasi dengan lingkungan tempat bekerja dalam rangka meningkatkan } \\
\text { efektivitas sebagai pendidik. } \\
\text { 3.2 Melaksanakan berbagai program dalam lingkungan kerja untuk mengembangkan } \\
\text { dan meningkatkan kualitas pendidikan di daerah yang bersangkutan. }\end{array}$ \\
\hline 4 & $\begin{array}{l}\text { Berkomunikasi dengan } \\
\text { komunitas profesi sendiri dan } \\
\text { profesi lain secara lisan dan } \\
\text { tulisan atau bentuk lain. }\end{array}$ & $\begin{array}{l}\text { 4.I Berkomunikasi dengan teman sejawat, profesi ilmiah, dan komunitas ilmiah } \\
\text { lainnya melalui berbagai media dalam rangka meningkatkan kualitas } \\
\text { pembelajaran. } \\
\text { 4.2 Mengkomunikasikan hasil-hasil inovasi pembelajaran kepada komunitas profesi } \\
\text { sendiri secara lisan dan tulisan maupun bentuk lain. }\end{array}$ \\
\hline
\end{tabular}

Dalam penelitian yang telah dilakukan, guru memberikan bimbingan kepada siapa saja yang bertanya dalam pembelajaran. Disamping itu, guru menjalin hubungan dengan peserta didik lewat candaan. Guru juga memberikan perhatiannya kepada peserta didik misalnya menegur dalam hal berpakaian, sopan santun dan lain sebagainya sebagaimana percakapan guru dan peserta didik di kelas. Dalam membina hubungan dengan peserta didik tidak hanya dilakukan di dalam kelas, tetapi di luar kelas beliau selalu memberikan perhatian kepada peserta didik. Dipertegas dengan penuturan peserta didik dalam wawancara langsung, bahwa ketika dalam kegiatan rohis beliau mampu menjadi teman bagi peserta didiknya. Guru merupakan ketua MGMP PAI di SMAN 2 Semarang, beliau juga pembina rohis. Kerjasama dengan guru yang lain ditunjukkan dalam setiap kegiatan, misalnya bekerjasama dalam pengelolaan dana untuk qurban Idul Adha. Kerjasama dengan orang tua dijalin lewat penyelesaian persoalan - persoalan yang dihadapi oleh peserta didik. beliau menggukan nasehat serta pendekatan yang baik agar dapat diterima oleh kedua pihak yaitu orang tua dan wali murid. Selain di sekolah, dalam masyarakat guru mengikuti macam - macam kegiatan seperti dasawisma, PKK, serta pengajian setiap minggu.

\section{d. Kompetensi Profesional}

Kompetensi profesional adalah kemampuan penguasaan materi pembelajaran secara luas dan mendalam yang memungkinkannya membimbing peserta didik memenuhi standar kompetensi yang ditetapkan dalam Standar Nasional Pendidikan. Selanjutnya akan disajikan indikator - indikator kompetensi profesional adalah sebagai berikut: 


\begin{tabular}{|c|c|c|}
\hline No & Kompetensi Inti & Kompetensi Guru Mata Pelajaran \\
\hline $\mathrm{I}$ & $\begin{array}{l}\text { Menguasai materi, struktur, } \\
\text { konsep, dan pola pikir keilmuan } \\
\text { yang mendukung } \\
\text { mata pelajaran yang diampu. }\end{array}$ & $\begin{array}{l}\text { I.I Menginterpretasikan materi, struktur, konsep, dan pola pikir ilmu-ilmu } \\
\text { yang relevan dengan pembelajaran Pendidikan Agama Islam. } \\
\text { I.2 Menganalisis materi, struktur, konsep, dan pola pikir ilmu-ilmu yang relevan } \\
\text { dengan pembelajaran Pendidikan Agama Islam. }\end{array}$ \\
\hline 2 & $\begin{array}{l}\text { Menguasai standar } \\
\text { kompetensi dan kompetensi } \\
\text { dasar mata pelajaran yang } \\
\text { diampu. }\end{array}$ & $\begin{array}{l}\text { 2.I Memahami standar kompetensi mata pelajaran yang diampu. } \\
\text { 2.2 Memahami kompetensi dasar mata pelajaran yang diampu. } \\
\text { 2.3 Memahami tujuan pembelajaran yang diampu. }\end{array}$ \\
\hline 3 & $\begin{array}{l}\text { Mengembangkan materi } \\
\text { pembelajaran yang diampu } \\
\text { secara kreatif. }\end{array}$ & $\begin{array}{l}\text { 3.I Memilih materi pembelajaran yang diampu sesuai dengan tingkat } \\
\text { perkembangan peserta didik. } \\
\text { 3.2 Mengolah materi pelajaran yang diampu secara kreatif sesuai dengan } \\
\text { tingkat perkembangan peserta didik }\end{array}$ \\
\hline 4 & $\begin{array}{l}\text { Mengembangkan keprofesionalan } \\
\text { secara berkelanjutan dengan } \\
\text { melakukan tindakan reflektif. }\end{array}$ & $\begin{array}{l}\text { 4.I Melakukan refleksi terhadap kinerja sendiri secara terus menerus } \\
\text { 4.2 Memanfaatkan hasil refleksi dalam rangka peningkatan keprofesionalan. } \\
\text { 4.3 Melakukan penelitian tindakan kelas untuk peningkatan keprofesionalan. } \\
\text { 4.4 Mengikuti kemajuan zaman dengan belajar dari berbagai sumber. }\end{array}$ \\
\hline 5 & $\begin{array}{l}\text { Memanfaatkan teknologi } \\
\text { informasi dan komunikasi } \\
\text { untuk mengembangkan diri. }\end{array}$ & $\begin{array}{l}\text { 5.I Memanfaatkan teknologi informasi dan komunikasi dalam berkomunikasi. } \\
\text { 5.2 Memanfaatkan teknologi informasi dan komunikasi untuk pengembangan } \\
\text { diri. }\end{array}$ \\
\hline
\end{tabular}

Guru dianggap sudah menguasai materi pembelajaran, hal ini di buktikan dengan berbagai pertanyaan dari peserta didik mampu dijawab oleh guru. Lewat penuturan peserta didik pula, dalam menjelaskan guru menggunakan bahasa yang mudah dipahami sehingga mereka tidak mengalami kesulitan dalam menerima materi pembelajaran. Guru juga mengatakan, materi yang diberikan kepada peserta didik seharusnya dianalisis dulu, materi seperti apa dan dengan metode apa yang sesuai dengan kemampuan peserta didiknya. Pemanfaatan teknologi yang digunakan oleh guru adalah penggunaan komputer dan LCD dalam penyampaian pembelajaran di kelas. Menurut penuturan salah satu guru yang menjadi rekan kerja beliau, Ibu Sadaria merupakan seorang yang bisa memanfaatkan IT dalam mengerjakan tugas - tugasnya.

\section{Kualifikasi Akademik Guru}

Dalam Permendiknas Nomor I6 Tahun 2007 dijelaskan bahwa "Guru pada SMA/MA, atau bentuk lain yang sederajat, diharuskan memiliki kualifikasi akademik pendidikan minimum sarjana (SI) program studi yang sesuai dengan mata pelajaran yang diajarkan/diampu, dan diperoleh dari program studi yang terakreditas»”. Dalam hasil penelitian ini diperoleh bahwa guru PAI telah menyelesaikan studi SI nya dengan jurusan PAI di IAIN Lampung. Kemudian melanjutkan pendidikan S2 nya di STIEPARI Semarang.

\section{KESIMPULAN}

I. Kompetensi Guru PAI di SMAN 2 Semarang

Kompetensi Guru PAI di SMAN 2 Semarang mempunyai pengaruh terhadap profesionalitas guru PAI. Keprofesionalan Guru PAI SMAN 2 Semarang ditunjukkan dengan pelaksanaan tugas - tugasnya dengan baik, tidak hanya lewat pengembangan kompetensi profesional dan kompetensi pedagogik saja. Akan tetapi yang lebih ditekankan pada tujuan pembelajaran agama Islam adalah bagaimana peserta didik mampu menerapkan nilai - nilai agama dan moral dalam kehidupan sehari-hari.

Dari hasil penelitian dan pembahasan yang diperoleh bahwa peserta didik mampu menerima materi dengan baik serta mengaktualisasikannya dalam kehidupan sehari-hari, bukan hanya karena kemampuan mengajar serta penguasaan materi yang baik oleh guru, akan tetapi pengaruh pribadi serta sosial guru yang memberikan sumbangan terbesar dalam pembentukan perilaku peserta didik.

2. Kualifikasi Akademik Guru PAI di SMAN 2 Semaran 
Kualifikasi akademik guru PAI SMAN di SMAN 2 Semarang merupakan kualifikasi yang sejalur dengan mata pelajaran yang diampu. Dengan mempunyai kualifikasi yang sejalur maka akan semakin dalam pula materi yang dimiliki oleh guru. Guru dengan kualifikasi akademi yang baik mampu menyampaikan materi dengan baik pula.

\section{DAFTAR PUSTAKA}

Depdiknas, 2003, Undang - Undang Republik Indonesia Nomor 20, Tahun 2003, tentang Sistem Pendidikan Nasional.

Depdiknas, 2005, Peraturan Pemerintah Republik Indonesia Nomor I9 Tahun 2005, tentang Standar Nasional Pendidikan.

Depdiknas, 2007, Permendiknas Republik Indonesia Nomor I6, Tahun 2007, tentang Standar Kualifikasi Akademik dan Kompetensi Guru

Kasiram, Moh., 20I0, Metode Penelitian Kualitatif Kuantitatif, Malang: UIN Maliki Press.

Kemendikbud, 2013, Peraturan Pemerintah Republik Indonesia Nomor 32, Tahun 2013, Tentang Standar Nasional Pendidikan

Majid, Abdul, 20II, Perencanaan Pembelajaran Mengembangkan Standar Kompetensi Guru, Bandung: PT Remaja Rosdakarya.

Moleong, Lexy J., 2012, Metodologi Penelitian

Kualitatif, Bandung: PT Remaja Rosdakarya.

Mudlofir, Ali, 2012, Pendidik Profesional Konsep Strategi dan Aplikasinya Dalam Peningkatan Mutu Pendidikan di Indonesia, Jakarta: PT Raja Grafindo Persada.

Mulyana, Dedy, 20I0, Metodologi Penelitian Kualitatif

Paradigma Baru Ilmu Komunikasi dan Ilmu Sosial

Lainnya, Bandung: PT. Remaja Rosdakarya.

Naim, Ngainun, 20II, Menjadi Guru Inspiratif Memberdayakan dan Mengubah Jalan Hidup Siswa, Yogyakarta: Pustaka Pelajar.

Putra, Nusa, 2012, Metode Penelitian Kualitatif Pendidikan, Jakarta: PT. Raja Grafindo Persada.

Sugiyono, 2013, Metode Penelitian Pendidikan

Pendekatan Kuantitatif, Kualitatif dan R\&D, Bandung: Alfabeta 